Stella Marega

University of Trieste, Italy

\title{
THE MEANINGS OF APOCALYPSE IN ERIC VOEGELIN'S LIFELONG ENQUIRY
}

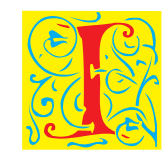

n December 1964, answering to the colleague Gregor Sebba, Eric Voegelin wrote him a letter containing a single sentence: "Today we are living in an age of apocalyptic politics." 1 The statement implied primarily a daunting concern for the devaluation of the term "apocalyptic", at that time so inflated by its redundant diffusion in Western imagery that every new attempt to approach the theme would have seemed unnecessary or at least irrelevant.

Nowadays things do not seem to be changed. Present (and future) wars, humanitarian crisis, rise of extremist and fundamentalist tendencies, but also climate changes, ecological disasters, exhaustion of natural resources, and many other phenomena are often labeled as "apocalyptic". The willingness to understand the reasons why the advanced, rational, secular Western society is still so dependent on an ancient, symbolic, religious word so much as to make of it the formula for the interpretation of most of the contemporary crisis, is legitimate.

The search for a convincing answer brings us back precisely to Eric Voegelin. It is well known that many modern interpretations about connections between religion and politics, political messianism, religious violence and also recent exploits of global terrorism are in debt, more or less explicitly, to his theories. It is less known that retracing Voegelin's philosophical itinerary, it turns out that the topic of Apocalypse not only crosses the whole his work, but also constitutes a key point in the comprehension of his philosophy.

The aim of this paper is to bring in evidence the progressive deepening of the role of the Apocalypse in Voegelin's intellectual path, making more clear why the apocalyptic theme stands as one of the dominant symbols in the self-interpretation of Western society.

1 E. Voegelin, Selected Correspondence 1950-1984 (Collected Works of Eric Voegelin), Baton Rouge, Louisiana: Louisiana State University Press, Vol. 30, 480-481. 


\section{Political symbols}

The most suitable starting point for a recognition on Voegelin's theory of apocalyptic symbolism is the 1938 essay Die politischen Religionen: ${ }^{2}$ a brilliant attempt to offer a clarification of the concept of "political religion" and together an interpretation of National Socialism. Moreover, it appeared also as a dispute against Hans Kelsen's doctrine of right, ${ }^{3}$ more precisely against its claim to stand as a substitute for a political theory. Although Voegelin acknowledged the strength of Kelsen's regulatory system and shared its theoretical validity, he rejected the idea of a reduction of the State in the narrow frame of a system of rules: a national system, argued the scholar, is rather the set of relationships between the state and its symbolic references.

The theoretical approach used by Voegelin was not welcomed at the time of publication: to question Kelsen's assumptions, and to propose the analysis of symbols as alternative to the theory of law, placed Voegelin in an unpopular position. The essay was criticized even by those intellectuals who, like Thomas Mann, disputed Voegelin's lack of firm denunciation of totalitarianism and advocated a more explicit moral critique. ${ }^{4}$

The aim of The Political Religions has been defended by Voegelin in the introduction to the 1939 edition, where he answered to criticism remembering that the struggle against National Socialism should not have been just ethical, because this would miss the essential core of the problem, since "a deeper and much more dangerous evil is hidden behind the ethically condemnable actions." $"$ The answer was sought instead in a more serious and deep crisis, grounded in the "secularization of the soul" and in the misleading renewal of the religious symbolism, that had brought the modern era to a tacit and guilty legitimacy of the forces of evil. Identifying and describing the religious roots of evil was therefore needed beyond a merely ethical critique, insufficient in the battle against the barbarism of the Dark Age. ${ }^{6}$

To prove his belief, Voegelin outlined an historical paradigm of the po-

2 E. Voegelin, Die politischen Religionen, ed. M. Henningsen, Wien, 1938. E. Voegelin, The Political Religions, in: Modernity without Restraint (Collected Works, Vol. 5), 19-73.

3 H. Kelsen, Das Problem der Souveranität und die Theorie des Völkerrechts. Beitrag zu einer Reinen Rechtslehre, Tübingen: Mohr, 1920.

4 Thomas Mann letter. Eric Voegelin Papers, Hoover Institution Archives, Box 24, file II.

5 E. Voegelin, Modernity without Restraint..., 24.

6 Ibidem, 25. 
litical religions, starting from the failed experience of the Egyptian empire of Amenophi IV, and analyzing the sacred symbols that gradually have followed over time by the disappearance of Egyptian state religion till the rise of modern national states: the solar symbol of Hierarchy, the Ecclesia or Corpus Mysticum, Spiritual and Temporal, Apocalypse, Leviathan and finally the whole concept of religious experience, that turns from faith into political obedience. All these religious symbols in the course of time have been emptied of their original sacred contents and transformed in supports of immanent experiences, with the consequence of legitimating erroneous intellectual and political constructions.

Among these symbols, that of Apocalypse undergoes major redefinitions and insights in Voegelin's later writings. Its importance is due to its function of representing not only the close derivation of the political symbolism from the religious one, but also the models of the development of history. Human history, indeed, is ordered through a symbolic interpretation founded on the premise that historical events represent "an expression of the will of God in history."

\section{Apocalypse and history}

In the chapter of The Political Religions dedicated to the symbol of Apocalypse, Voegelin argues that the sequence of Western symbolic interpretations of history had its origins with St. Paul and was developed later by Augustine, achieving its most significant step in the twelfth Century thanks to the Calabrian abbot Joachim of Fiore. Interpreting the correspondences between the Old and the New Testament, Joachim hypothesized the existence of a tripartite division of history in three eras: the realm of the Father (from Adam to Christ), the realm of the Son (from Christ to 1260) and the realm of the Holy Ghost (from 1260 till the Day of Judgment). The crucial factor in Joachim's theology was not the division of history in three ages, but the determination to consider the Third Kingdom, the realm of ultimate perfection, like an imminent era of completeness and a time of spiritual renewal that would bring peace on Earth. Thanks to a method of interpretation called by Voegelin "the formula for a spiritual and intellectual movement", Joachim's tripartite division of history settled that the last time would have been not represented by the Church of Christ, but by the future spreading of the Holy Spirit.

\footnotetext{
${ }^{7}$ Ibidem, 50.
} 
Joachim's interpretation was absorbed at first by the Franciscan spiritualists, who identified in Francis of Assisi the dux of the apocalyptic prophecy, and in the monastic community the replacement of the worldly Church. In the apocalyptic symbol were placed therefore the expectations for the earthly realization of the perfect realm of peace and freedom; the hopes that the Church poured into the afterlife have been transformed in the belief of the realization of an immanent perfect kingdom. Joachim's theology of history, in other words, "forms the historical basis for the apocalyptic dynamics in modern political religions."

\section{The problem of gnosticism}

The issue of apocalyptic symbolism has been subsequently fulfilled in a series of lectures gave in 1951 at the University of Chicago and collected in The New Science of Politics, ${ }^{9}$ one of Voegelin's most successful publications. The aim of the work was to identify the reasons of the "pathological condition of modernity", consisting precisely in a range of wrong ideological constructions as historicism and positivism and political ideologies as Marxism, Fascism and Nazism.

In The New Science the problem of Apocalypse is connected mainly with Gnosticism: not surprisingly, this has caused many problems of understanding. Voegelin's reference to Gnosticism is due to its soteriological doctrine, alternative to Christian doctrine of salvation. In the original Gnostic belief the world was considered corrupt and evil, and salvation was considered possible only through an escape from material existence, through the awareness of the divine nature of every man and thanks to the illumination given by gnosis, which means precisely "knowledge".

Around the 2nd Century Gnosticism was outclassed by the spread of Christianity and remained only an underground current. When secularization led to the end of Christian belief in the afterlife, men, feeling the need to find a substitute for faith, found it in what Voegelin called "modern Gnosticism". The term doesn't indicates a religious doctrine or a structured movement, but rather an attitude, a way of thinking and action.

\section{Ibidem, 51.}

9 E. Voegelin, The New Science of Politics: An Introduction, Chicago: University of Chicago Press, 1987. 
As in ancient Gnostic doctrine, in modern Gnosticism the world is considered still evil and corrupt, but salvation is deemed possible within the reach of human action. Salvation can be achieved not thanks to knowledge of the divine spark as in the ancient Gnosticism, not thanks to divine grace as in Christianity, but thanks to a human intervention that makes possible a change of the conditions of existence.

Voegelin identified the origin of modern Gnosticism in the secularization of the supernatural expectations, a phenomenon he defined with the formula "immanentization of the eschaton": the concept includes the transfiguration of the symbol of the Apocalypse, moving from a transcendent level to an historical one.

According to Voegelin this process began exactly with the reception of Joachim of Fiore's theory of the Third Kingdom, and should be seen as the first step in a process of culpable and deliberate denial of the reality of history. Voegelin argues that modern thought has, in many ways, taken over the Joachimitic idea of the Third Kingdom, using it for the creation and development of new historical paradigms: the age of positive science for Comte, the realm of freedom for Hegel, the classless society for Marx and Engels. In all these cases, the idea of the Final Kingdom has been transfigured and filled in with revolutionary expectations.

Voegelin still developed this thesis, radicalizing further in two successive essays collected in the work Science, Politics and Gnosticism. ${ }^{10}$ In these writings he highlights how the transfiguration of the symbol of Apocalypse invests the level of history and the anthropological dimension of the man with hazardous political and ideological connotations. The assignment to history of a transcendent purpose that in reality it does not own, forces modern man to pour all his energies in the final transformation of the inner-worldly reality: an expectation that will never find full satisfaction.

\section{Metastasis of history}

Simultaneously to the studies on the Gnostic character of modern mass movements, Voegelin also investigated the problem of the decline of messianism, a phenomenon strictly connected with the arise of the inner-worldly apoca-

10 E. Voegelin, Science, Politics and Gnosticism: Two Essays, in: Modernity without Restraint, ed. M. Henningsen, Washington D.C.: Regnery Gateway, 1968, 243-313. 
lypse. Interesting developments were presented at a conference in 1959, ${ }^{11}$ where he underlined the necessity to coin a new term that would exceed the concept of Gnosticism and that should identify more precisely the belief in the transfiguration of the human nature. This term is metastasis: it indicates the movement of reality beyond the present structure of order, into a new state.

Metastasis means for Voegelin the change in the constitution of being envisaged by the prophets, a trend felt again in modern world after the disintegration of the precarious medieval Christian synthesis and also evident with the emergent spiritual crisis of the modern world. At the beginning of the eighteenth Century, indeed, the transcendental faith sustaining the eschatological symbolism was swept away by the spread of secularism, while the old apocalyptic symbolism was replaced by a new kind of messianism, a school of thought called "philosophy of history".

The metastasis itself became a new sort of faith that opened the way to the apocalyptic tendencies in modern world: "When the transfiguration through a royal act of faith does not occur, and the political disaster reach insurmountability, the metastatic type of speculation then gives way to the apocalyptic type, which expects disorder of catastrophic magnitude to be ended by divine intervention." 12

Elaborating the concept of metastasis, which will become one of the most significant and recurring concepts in his philosophy, Voegelin comes also to the discover that Gnosis and Apocalypse have developed about at the same time, but independently; moreover, both are not directly linked to the immanentization of the eschaton. While Gnosis concerns a human knowledge for the transformation of reality, the metastatic apocalypse derives from the Israelite prophets' belief in a transfiguration of reality through an act of faith. ${ }^{13}$

\section{From history to consciousness}

In 1965 Voegelin gave a series of lectures, the Geschichtsphilosophie Vorlesung, where he faced three main problems: the theoretical problem of the idea of progress, the philosophy of history as part of the revolutionary practice, the

11 E. Voegelin, "The West and The Meaning of Industrial Society", in: The Drama of Humanity and Other Miscellaneous Papers 1939-1985 (Collected Works, Vol. 33), 89-111.

12 E. Voegelin, Order and History, Volume V, In Search of Order (Collected Works, Vol. 18), 48.

13 E. Voegelin, Autobiographical Reflections (Collected Works, Vol. 34), 93-95. 
apocalyptic structure of history. ${ }^{14}$ While working on these materials, Voegelin had already reached a new important acquisition which had a major influence on all of his subsequent philosophy. The finding concerned the impossibility of separating the historical dimension from the existential one. Since the order of consciousness originates the problems of the human order in society and history, Voegelin guessed that the order of human existence finds its foundation in consciousness: this brought the need to include the philosophy of history into the broader context of the philosophy of consciousness.

The implications of the transition to the philosophy of consciousness are clearly expressed in Anamnesis, ${ }^{15}$ a key work of reflection on the nature of consciousness and the method of philosophical analysis. Anamnesis (a term Voegelin borrows from Plato, meaning recollection of a prior being) is the meditative process through which can emerge the philosophy of order: Consciousness is an experience of participation in the ground of being and not something given that can be deducted as a theory. Theory, indeed, is an illusion.

At this stage of Voegelin's enquiry the contents change, as well as the goals have changed: the research on political tension, and consequently on the apocalyptic voltage, moves to an existential quest about the underlying tension from which disorder arises.

The crucial points in the development of Voegelin's philosophy of consciousness became clear during the writing of Ecumenic Age, a complex effort which took 17 years and led the scholar to break his original project on history of order started in 1956 with Israel and Revelation. The awareness was the unavoidable shattering of the structure of unilinear history. "Voegelin gradually realized that many societies, religions, thinkers, and politicians from ancient Sumeria to present-day Fourth of July speakers had symbolized history as a unilinear stream of meaning that began in a mythical past and culminated in their own existences", explains James Rhodes, "Apparently, there is a deep-seated urge in the human spirit to view the passage of time this way. Unhappily, history had to be falsified to get the lines of meaning to work. There was no cycle, no course of history such as The New Science had proclaimed." ${ }^{16}$ History does not exist: there is a drama of history, but its meaning

${ }^{14}$ E. Voegelin, "Geschichtsphilosophie. Vorlesung Sommer Semester 1965”, München: Occasional Papers, Eric-Voegelin-Archiv, No.68 (July, 2008).

15 E. Voegelin, Anamnesis: On the Theory of History and Politics (Collected Works, Vol. 6).

${ }^{16}$ J. M. Rhodes, "On Voegelin: His Collected Works and His Significance," The Review of Politics, Vol. 54, No. 4, Autumn, 1992, 621-647. 
is unknowable; there are facts in history, but their interpretation is subjective. The "patterns of meaning" do not develop in an univocal and linear sense but in an inextricable "web structure" "that had to be followed "backward and forward and sideways."”17

Apocalypse does not represent more the structure of the unilinear history but takes on another nuance: it is configured as historiogenesis, ${ }^{18}$ a construct that reveals the "obsession with unilinear history", a sort of symbolisms "created to assuage the anxiety of existence." 19

\section{The practice of dying}

Without claiming to put an end point in this survey, is still possible make some concluding remarks related to the existential value of the Apocalypse in Voegelin's thought. In the essay Eschatology and Philosophy. The Practice of Dying, ${ }^{20}$ the apocalyptic theme takes on a further, important meaning, linked to the transcendent nature of man and to the eschatological tension of history.

Voegelin argues that, if philosophy wants to deal with the problem of history, it should acknowledge its fundamental eschatological character: the process of history indeed is not immanent, but moves in the in-between of this-worldly and other-worldly reality. Man's nature therefore is not a constant, as classical philosophers knew, because the human itself participates in the eschatological movement of history.

Man's existence is ordered by the awareness of his eschatological destiny: "this does not mean than the nature of man can be transfigured within history" but that man's nature "become luminous for its eschatological destiny". ${ }^{21}$ Men are directed toward eschatological perfection, but their "pilgrimage" is still a worldly route.

Furthermore, while history is characterized by a tension toward the beyond, human movement beyond the structure of reality is a movement beyond

\section{Ibidem.}

${ }^{18}$ E. Voegelin, "Anxiety and Reason", in: What is History? And Other Late Unpublished Writings (Collected Works, Vol. 28), 52-110.

19 Thomas A. Hollweck and Paul Caringella, Editors' Introduction to What is History?, xxi.

20 E. Voegelin, "Eschatology and Philosophy. The Practice of Dying”, in: Autobiographical Reflections (Collected Works, Vol. 34), 145-148.

21 Ibidem, 147. 
death. Voegelin, gathering the legacy of Classical philosophy, calls this movement athanaizen, which means "to immortalize". The apocalyptic tension arises when individuals are not able to attune their life with this movement: the desire of a "shortcut to perfection" requires a change in the structure of being and, as Voegelin had already figured out, the transmutation of reality can only be obtained by violence and destruction.

\section{References}

Hollweck, T. A. and P. Caringella (eds.), "Introduction," in: What is History? And Other Late Unpublished Writings (Collected Works, Vol. 28), Columbia: University of Missouri, 1990, 52-110.

Mann, T., "Letter to Eric Voegelin," in: Eric Voegelin Papers, Hoover Institution Archives: Box 24, file II.

Rhodes, J. M., "On Voegelin: His Collected Works and His Significance," The Review of Politics 54.4, 1992, 621-647.

Voegelin, E., Anamnesis: On the Theory of History and Politics (Collected Works, Vol. 6), Columbia: University of Missouri Press, 2002.

Voegelin, E., "Anxiety and Reason," What is History? And Other Late Unpublished Writings (Collected Works, Vol. 28), Columbia: University of Missouri, 1990, 52-110.

Voegelin, E., Autobiographical Reflections (Collected Works, Vol. 34), Columbia: University of Missouri Press, 2006.

Voegelin, E., Die politischen Religionen, ed. M. Henningsen, Wien, 1938. The Political Religions, in: Modernity without Restraint (Collected Works, Vol. 5), 19-73.

Voegelin, E., "Geschichtsphilosophie. Vorlesung Sommer Semester 1965," Occasional Papers, München: Eric-Voegelin-Archiv 68, 2008.

Voegelin, E., Order and History, Volume V, In Search of Order (Collected Works, Vol. 18), Columbia: University of Missouri Press, 1999.

Voegelin, E., "Science, Politics and Gnosticism: Two Essays," Modernity without Restraint, M. Henningsen (ed.), Washington, DC: Regnery Gateway, 1968, 243-313.

Voegelin, E., Selected Correspondence 1950-1984 (Collected Works of Eric Voegelin), Columbia and London: University of Missouri Press, 2007.

Voegelin, E., The New Science of Politics: An Introduction, Chicago: University of Chicago Press, 1987.

Voegelin, E., "The West and The Meaning of Industrial Society," The Drama of Humanity and Other Miscellaneous Papers 1939-1985 (Collected Works, Vol. 33), Columbia: University of Missouri Press, 2004, 89-111. 